\title{
Rapid and gradual modes of aerosol trace metal dissolution in seawater
}

\author{
Katherine R. M. Mackey ${ }^{1}$, Chia-Te Chien ${ }^{2}$, Anton F. Post ${ }^{3}$, Mak A. Saito $^{4}$ and Adina Paytan ${ }^{5}$ \\ 'Earth System Science, University of California, Irvine, Irvine, CA, USA \\ ${ }^{2}$ Department of Earth and Planetary Sciences, University of California, Santa Cruz, Santa Cruz, CA, USA \\ ${ }^{3}$ Graduate School of Oceanography, University of Rhode Island, Narragansett, RI, USA \\ ${ }^{4}$ Marine Chemistry and Geochemistry, Woods Hole Oceanographic Institution, Woods Hole, MA, USA \\ ${ }^{5}$ Institute for Marine Science, University of California, Santa Cruz, Santa Cruz, CA, USA
}

\section{Edited by:}

William Sunda, National Oceanic and Atmospheric Administration, USA

\section{Reviewed by:}

Peter Croot, National University of Ireland, Galway, Ireland

Katherine Barbeau, University of California, San Diego, USA

Yeala Shaked, Hebrew University, Israel

*Correspondence:

Katherine R. M. Mackey, Earth System Science, University of California, Irvine, 3204 Croul Hall, Irvine, CA 92697, USA

e-mail: kmackey@uci.edu
Atmospheric deposition is a major source of trace metals in marine surface waters and supplies vital micronutrients to phytoplankton, yet measured aerosol trace metal solubility values are operationally defined, and there are relatively few multi-element studies on aerosol-metal solubility in seawater. Here we measure the solubility of aluminum (Al), cadmium $(\mathrm{Cd})$, cobalt $(\mathrm{Co})$, copper $(\mathrm{Cu})$, iron $(\mathrm{Fe})$, manganese $(\mathrm{Mn})$, nickel $(\mathrm{Ni})$, lead $(\mathrm{Pb})$, and zinc (Zn) from natural aerosol samples in seawater over a 7 days period to (1) evaluate the role of extraction time in trace metal dissolution behavior and (2) explore how the individual dissolution patterns could influence biota. Dissolution behavior occurs over a continuum ranging from rapid dissolution, in which the majority of soluble metal dissolved immediately upon seawater exposure ( $\mathrm{Cd}$ and $\mathrm{Co}$ in our samples), to gradual dissolution, where metals dissolved slowly over time ( $\mathrm{Zn}, \mathrm{Mn}, \mathrm{Cu}$, and $\mathrm{Al}$ in our samples). Additionally, dissolution affected by interactions with particles was observed in which a decline in soluble metal concentration over time occurred ( $\mathrm{Fe}$ and $\mathrm{Pb}$ in our samples). Natural variability in aerosol chemistry between samples can cause metals to display different dissolution kinetics in different samples, and this was particularly evident for $\mathrm{Ni}$, for which samples showed a broad range of dissolution rates. The elemental molar ratio of metals in the bulk aerosols was 23,189Fe: 22,651 Al: 445Mn: 348Zn: 71 Cu: 48Ni: 23Pb: 9Co: $1 \mathrm{Cd}$, whereas the seawater soluble molar ratio after 7 days of leaching was $11 \mathrm{Fe}$ : $620 \mathrm{Al}$ : 205Mn: 240Zn: 20Cu: 14Ni: 9Pb: 2Co: 1Cd. The different kinetics and ratios of aerosol metal dissolution have implications for phytoplankton nutrition, and highlight the need for unified extraction protocols that simulate aerosol metal dissolution in the surface ocean.

Keywords: aerosols, atmospheric deposition, phytoplankton, trace metals, ligands

\section{INTRODUCTION}

The role of atmospheric nutrient deposition in supporting marine phytoplankton growth is well documented (Peierls and Paerl, 1997; Herut et al., 1999; Mills et al., 2004; Duce et al., 2008; Mackey et al., 2012a,c). Determination of bioavailable nutrient and trace metal content in aerosols is based on laboratory extraction methods that generate operationally-defined solubility patterns sensitive to extraction volume, solvent $\mathrm{pH}$, mechanical agitation, and other factors. In this study, we investigate the role of extraction time on aerosol leaching kinetics, with the goal of characterizing the dissolution chemistry of a suite of trace metals $(\mathrm{Al}, \mathrm{Cd}, \mathrm{Co}, \mathrm{Cu}, \mathrm{Fe}, \mathrm{Mn}, \mathrm{Ni}, \mathrm{Pb}$, and $\mathrm{Zn}$ ) and understanding the impact of these characteristics on marine biota.

Atmospheric deposition of nitrogen $(\mathrm{N})$ and phosphorus $(\mathrm{P})$ provide nutrition in open ocean (Duce et al., 2008; Mackey et al., 2012a,c) and coastal areas (Paerl, 1997; Peierls and Paerl, 1997; Herut et al., 1999), and atmospheric $\mathrm{N}$ deposition may supply $40-70 \%$ of the total nitrate to phytoplankton in the North Pacific Ocean (Prospero and Savoie, 1989). Phytoplankton growth can be stimulated by these macronutrient additions as demonstrated in mesocosm (Guieu et al., 2010, 2014; Laghdass et al., 2011; Giovagnetti et al., 2013; Ridame et al., 2013; Wuttig et al., 2013c) and shipboard incubation experiments (Mills et al., 2004; Davey et al., 2008; Langlois et al., 2012). Deposition of iron (Fe) is another important source of growth-sustaining nutrition for phytoplankton, and atmospheric deposition is a primary source of $\mathrm{Fe}$ to many regions of the ocean (Duce and Tindale, 1991; Mills et al., 2004; Mahowald et al., 2005; Moore et al., 2006; Baker and Croot, 2010).

In recent years the biological effects of metals other than $\mathrm{Fe}$ derived from atmospheric deposition have received increasing attention (Jordi et al., 2012; Mackey et al., 2012a; Wuttig et al., 2013c). Biologically relevant metals such as $\mathrm{Cd}, \mathrm{Co}, \mathrm{Cu}, \mathrm{Mn}$, $\mathrm{Ni}$, and $\mathrm{Zn}$ are cofactors in a wide range of microbial enzymes (Morel et al., 1994; Morel and Price, 2003 and references therein; Saito et al., 2011). Metal micronutrients can limit or co-limit phytoplankton growth (Saito et al., 2002; Saito and Goepfert, 2008); however, in high concentrations metals can cause toxicity 
(Paytan et al., 2009; Jordi et al., 2012). Biological metal uptake is also apparent for certain metals from depth profiles even in areas where metals do not necessarily limit growth (e.g., $\mathrm{Zn}$ and Co, Saito and Moffett, 2002; Noble et al., 2008), whereas the profiles of other metals are more strongly influenced by abiotic factors despite their critical biological roles (e.g., Mn, Noble et al., 2008). Similar to Fe, input of metals from atmospheric deposition of crustal and anthropogenic particles may be the main source of these metals to certain regions, particularly the open ocean where other geological sources (rivers, groundwater) are minor. Phytoplankton growth responses to seawater soluble metals from atmospheric deposition has been observed following natural (Jordi et al., 2012) and simulated (Mackey et al., 2012a) deposition events.

Because investigation of the biological role of metal deposition is still relatively new, much of our predictive capacity comes from atmospheric deposition models. By making assumptions about deposition rates, total metal content, and metal solubility, these models predict the amount of metal that will dissolve in seawater following deposition on the ocean's surface. For these models the concept of "solubility" and "fractional solubility" are important. Baker and Croot (2010) define metal solubility as being operationally determined by measuring metal concentrations in filtrate after passing through a filter containing the aerosol sample. Fractional solubility is defined as the portion of metal that dissolves from an aerosol sample, and is determined from the metal content in the filtrate divided by the total metal content of the aerosol added to the solution (Baker and Croot, 2010). Both of these parameters are operationally defined and sensitive to experimental protocols.

Aerosol leaching procedures differ considerably from conditions in the surface ocean. Metal solubility estimates are typically made by extracting aerosol samples under controlled conditions using pure water or buffered acidic solvents that approximate rain water (Anderson et al., 2010 and references therein). At the same time a number of factors can influence metal dissolution during experiments. Different aerosol mineralogical properties and atmospheric particle processing strongly influences aerosol metal solubility (Desboeufs et al., 1999, 2001, 2003, 2005; Jones and Gislason, 2008; Journet et al., 2008; Paris et al., 2010, 2011; Paris and Desboeufs, 2013).

The composition and history of the seawater used in dissolution experiments has also been found to influence the solubility of Fe and other elements. For example, seawater superoxide and hydrogen peroxide levels (Heller and Croot, 2011; Wuttig et al., 2013a,b) as well as ligand content (Saito et al., 2005; Mackey et al., 2012a) exert control on seawater metal chemistry, potentially influencing the dissolution of metals from aerosols. The solvent used in a dissolution experiment likewise influences solubility measurements made in the laboratory (see Table 1 for chemistry of seawater used in this study). Chen et al. (2006) directly compared the solubility of a suite of metals in aerosol samples extracted in pure water and seawater. While certain metals, such as $\mathrm{Zn}$, had similar solubility in the two solvents, others metals like $\mathrm{Fe}$ and $\mathrm{Al}$ were much less soluble in seawater than in pure water.

Other studies have directly investigated Fe solubility in seawater (Zhuang et al., 1990; Zhu et al., 1997; Bonnet and Guieu, 2004; Buck et al., 2006, 2013), however in these studies the duration and degree of mechanical agitation have all varied, thus it is difficult to compare the results. For example, up to $60 \%$ of the variability in trace metal solubility can be attributed to the type of filter used to collect the aerosol samples (Buck and Paytan, 2012). Difficulty comparing across data sets limits the accuracy of biogeochemical models that incorporate these data. Boyd et al. (2010) conducted an extensive review of aerosol Fe solubility measurements and biogeochemical modeling approaches for atmospheric Fe deposition. They conclude that uncertainty in Fe solubility estimates and model parameters have led to an overstatement of the relationship between dust supply and biological response, and argue that to improve biogeochemical model accuracy for Fe deposition it is necessary to standardize dissolution methodologies.

In natural waters, trace metal solubility is affected by aerosol properties (particle size, composition, source, transport distance, etc.), seawater chemistry, biological ligand concentration, and photochemistry (Figure 1; Barbeau et al., 2001; Aguilar-Islas

Table 1 | Concentrations of trace metals in seawater used in the leaching experiments.

\begin{tabular}{|c|c|c|c|c|}
\hline Metal & $\begin{array}{c}\text { Background seawater } \\
\text { concentration, this study (ng/L) }\end{array}$ & $\begin{array}{c}\text { Background seawater } \\
\text { concentration, this study (nmol/L) }\end{array}$ & $\begin{array}{l}\text { Coefficient of } \\
\text { variation }(\%)^{*}\end{array}$ & $\begin{array}{c}\text { Typical atlantic ocean surface } \\
\text { concentration (nmol/L) }\end{array}$ \\
\hline $\mathrm{Al}$ & 517 & 19.2 & 21 & $33^{a}$ \\
\hline $\mathrm{Cd}$ & 12 & 0.11 & 6 & $0.014^{b}$ \\
\hline Co & 0.55 & 0.0093 & 21 & $0.017^{c}$ \\
\hline $\mathrm{Cu}$ & 30 & 0.47 & 11 & $1.15^{d}$ \\
\hline $\mathrm{Fe}$ & $\mathrm{DL}$ & DL & 19 & $0.08^{b}$ \\
\hline $\mathrm{Mn}$ & 32 & 0.58 & 7 & $0.76^{e}$ \\
\hline $\mathrm{Ni}$ & 141 & 2.4 & 10 & $2.05^{d}$ \\
\hline $\mathrm{Pb}$ & 2.2 & 0.012 & 3 & $0.05^{f}$ \\
\hline $\mathrm{Zn}$ & 318 & 4.86 & 30 & $0.04^{d}$ \\
\hline
\end{tabular}

$D L$, below detection limit.

* determined from time zero measurement of 4 seawater-only operational blank replicates.

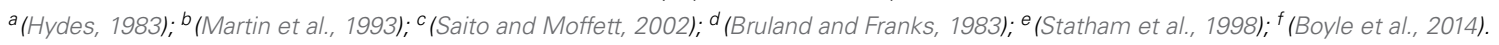




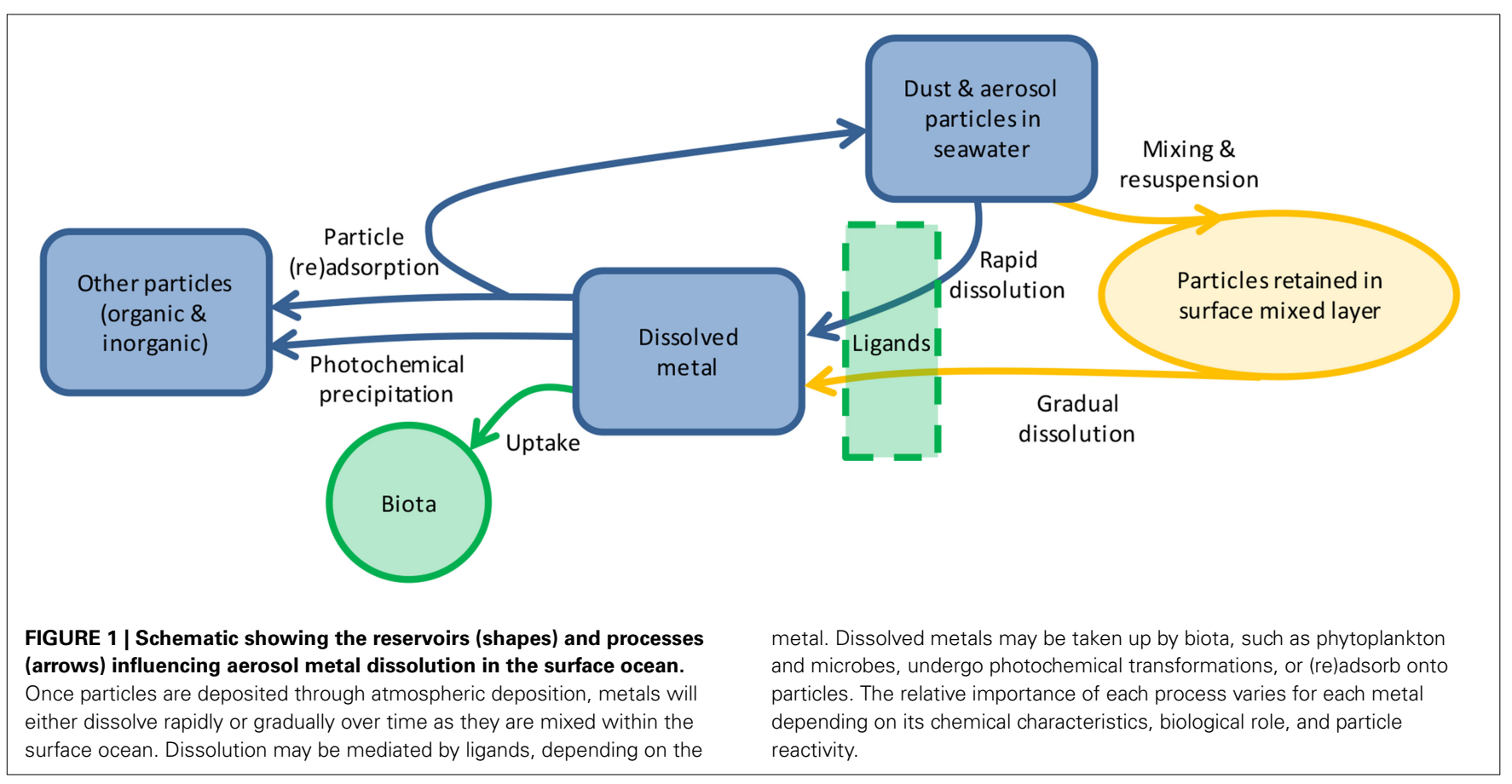

et al., 2010; Measures et al., 2010; Buck et al., 2013). Less is known about how the duration of particle interaction with the solution affects the dissolution of metals from aerosols. The residence time of particulate metals in the upper water column ranges from days to months [e.g., particulate Fe is 6-62 days (Croot et al., 2004) and particulate $\mathrm{Al}$ is 3-22 days (Dammshäuser et al., 2013)], yet many leaching protocols occur over seconds to hours (Buck et al., 2006; Chen et al., 2006). Longer leaching time has been shown to increase the dissolution of P (Ridame and Guieu, 2002; Mackey et al., 2012c) and some metals in seawater (e.g., Al, Co Fe, Mn, Zn; Boyd et al., 2010; Measures et al., 2010; Mendez et al., 2010; Thuroczy et al., 2010); however, information on dissolution of many biologically important metals from the same samples using the same extraction procedures is needed. In this study we investigated the dissolution behavior of nine aerosol metals in seawater over a 7 days time course. We found that metal dissolution behavior falls along a continuum and is characterized by significant inter-sample variability, with important ecological and modeling implications.

\section{MATERIALS AND METHODS AEROSOL COLLECTION}

Samples were collected with a Total Suspended Particle (TSP) High Volume Sampler (HVS) at the shoreline of the Gulf of Aqaba, Red Sea at the Inter-University Institute for Marine Science $\left(29^{\circ} 31^{\prime} \mathrm{N}, 34^{\circ} 55^{\prime} \mathrm{E}\right)$ as described in Chen et al. (2006). Samples were collected over 3 days periods at a flow rate of $1.2-1.5 \mathrm{~m}^{3} \mathrm{~h}^{-1}$, and approximately $200 \mathrm{~m}^{3}$ of air was filtered. The sampler collects all particles greater than $0.2 \mu \mathrm{m}$ and does not have an upper limit size cutoff. The particle size distributions are given in Table 2, and were made using a GT-321 Handheld Particle Counter. The size classes included 0.3, 0.5, 1,3 , and $5 \mu \mathrm{m}$. Samples were collected on acid-cleaned, milliQ water-rinsed $47 \mathrm{~mm}$ polycarbonate membrane filters (Isopore) and sealed frozen in plastic petri dishes until use. Three replicate filters were collected over each 3 day sampling period, and duplicate filters from the same sampling period were combined in the dissolution experiment described below. The third filter was used to determine total metal content in the aerosol particles following heated digestion with nitric and hydrofluoric acid as described in Chen et al. (2006). Filters were weighed before and after sample collection and were totally dry when weighed. Aerosol mass was determined by subtraction and the precision was $0.01 \mathrm{mg}$.

\section{DISSOLUTION EXPERIMENT}

To determine the effect of extended seawater contact on aerosol trace metal dissolution, experiments were performed with natural TSP samples in low nutrient, low metal seawater collected from the South Atlantic Ocean (13.480 S 0.040 W, $8 \mathrm{~m}$ depth, salinity 36.4). Seawater was aged over 1 year at room temperature in a polyethylene carboy under trace metal clean conditions in the dark and $0.2 \mu \mathrm{m}$ filtered immediately before use. Six distinct TSP samples on whole filters were added separately to $300 \mathrm{~mL}$ of seawater in $500 \mathrm{~mL} \mathrm{10 \%} \mathrm{hydrochloric} \mathrm{acid} \mathrm{cleaned} \mathrm{polycar-}$ bonate bottles and incubated in the dark on a rotary shaker on medium speed. Two operational blanks were included using acid cleaned filters rather than true samples, and were incubated, sampled, and analyzed identically to the real samples. At each time point the bottles were shaken and $13 \mathrm{~mL}$ aliquots were removed by pouring from the bottle into freshly acid cleaned syringes, filtered through $0.2 \mu \mathrm{m}$ polypropylene syringe filters, and stored in $15 \mathrm{~mL}$ centrifuge tubes at room temperature until analysis. All sampling was done in a class 100 clean room within a laminar flow hood equipped with HEPA filter and no metal parts or metal equipment. Sampling time points occurred immediately following sample addition (within $10 \mathrm{~min}$ ) and then after 
Table 2 | Aerosol properties. Particle size ranges are the average of 10 measurements by the particle counter.

\begin{tabular}{|c|c|c|c|c|c|c|c|c|}
\hline $\begin{array}{l}\text { Aerosol } \\
\text { collection } \\
\text { start date }\end{array}$ & $\begin{array}{l}\text { Aerosol } \\
\text { collection } \\
\text { end date }\end{array}$ & $\begin{array}{c}\text { Total suspended } \\
\text { particle } \\
\text { concentration } \\
(\mu \mathrm{g} / \mathrm{m} 3)\end{array}$ & $\begin{array}{l}\text { Total aerosol } \\
\text { mass (mg) }\end{array}$ & $\begin{array}{l}\geq 5 \text { um } \\
\text { (particles/L) }\end{array}$ & $\begin{array}{l}\geq 2 \text { um } \\
\text { (particles/L) }\end{array}$ & $\begin{array}{l}\geq 1 \mathrm{um} \\
\text { (particles/L) }\end{array}$ & $\begin{array}{l}\geq 0.5 \text { um } \\
\text { (particles/L) }\end{array}$ & $\begin{array}{c}\geq 0.3 \text { um } \\
\text { (particles/L) }\end{array}$ \\
\hline 2/26/2006 & 3/1/2006 & 22 & 12.6 & 186 & 1401 & 2356 & 5960 & 86403 \\
\hline 5/7/2006 & 5/10/2006 & 77 & 9.1 & 91 & 854 & 2127 & 13404 & 177820 \\
\hline 6/11/2006 & 6/14/2006 & 43 & 6.7 & 280 & 2327 & 4075 & 7437 & 63767 \\
\hline 6/15/2006 & 6/18/2006 & 44 & 8.0 & 167 & 2676 & 5077 & 10870 & 153522 \\
\hline 7/9/2006 & $7 / 12 / 2006$ & 29 & 5.2 & ND & ND & 1705 & 3905 & 60958 \\
\hline $3 / 12 / 2006$ & $3 / 15 / 2006$ & 97 & 9.8 & 317 & 2780 & 4421 & 8045 & 37915 \\
\hline $3 / 12 / 2006$ & $3 / 15 / 2006$ & 97 & 6.6 & 317 & 2780 & 4421 & 8045 & 37915 \\
\hline
\end{tabular}

$N D=$ not determined.

$6 \mathrm{~h}, 1$ day, 3 days, and 7 days of soaking. Blank seawater containing no aerosol was also collected at time zero to determine the background concentration of metals.

The particle to solvent ratio is known to affect solubility of nutrients and trace metals from aerosols, where higher particle loads can reduce the solubility of certain metals due to readsorption onto particle surfaces (Baker et al., 2006). Differences in particle load existed in this experiment (Table 2). To determine the effect of particle load on metal dissolution in this study, we incubated one sample at two particle concentrations. For this sample $(3 / 12 / 2006)$ one bottle received $9.8 \mathrm{mg}$ of sample and another bottle received $6.6 \mathrm{mg}$ of sample, and both were added to $300 \mathrm{~mL}$ of seawater.

This aerosol loading is on the high end of values for similar metal leaching studies. Natural aerosol loadings in the ocean vary by site depending on the TSP concentration in air and the depositional velocity. For example, in areas of relatively high deposition such as near Cape Verde and in the Gulf of Aqaba, aerosol loadings of 1-2 $\mathrm{mg} \mathrm{L}^{-1}$ have been employed (Paytan et al., 2009; Heller and Croot, 2011). The aerosol loadings used here were higher (1742 $\left.\mathrm{mg} \mathrm{L}^{-1}\right)$ compared to prior published datasets where values from 10 to $100 \mathrm{mg} \mathrm{L}^{-1}$ were used (Chen et al., 2006; Buck and Paytan, 2012).

\section{TRACE METAL COLUMN CHEMISTRY AND ANALYSIS}

Seawater samples from the dissolution experiment were acidified to $\mathrm{pH}<2.0$ with concentrated trace metal grade nitric acid (final concentration $0.02 \mathrm{M}$ ) at least $48 \mathrm{~h}$ before removal from their storage tubes. The $\mathrm{pH}$ was then adjusted to six with ammonium acetate (final concentration $0.05 \mathrm{M}$ ) and ammonium hydroxide (final concentration $0.027 \mathrm{M}$ ) prior to column chemistry. Trace metals were concentrated using Nobias Chelate-PA1 resin (HITACHI High Technologies, Japan) to remove the seawater matrix (Sohrin et al., 2008; Biller and Bruland, 2012). Metals were eluted with $1 \mathrm{M}$ trace metal grade nitric acid; method detection limits and recovery are given in the online Supplemental Material. The $5 \mathrm{~mL}$ eluent from each sample was analyzed for $\mathrm{Al}, \mathrm{Cd}, \mathrm{Co}, \mathrm{Cu}, \mathrm{Fe}, \mathrm{Mn}, \mathrm{Ni}, \mathrm{Pb}$, and $\mathrm{Zn}$ by HR-ICPMS (Thermo Element XR). Samples were introduced into the instrument with a peristaltic pump at a flow rate of $\sim 120 \mu \mathrm{L} \mathrm{min}^{-1}$ and passed through an ESI-PC3 Peltier cooled spray chamber before entering the torch. Sample and gas flow rates were optimized for each run; values were $0.75-0.80 \mathrm{ml} \mathrm{min}^{-1}$ and $0.20-0.24 \mathrm{ml} \mathrm{min}^{-1}$, respectively. Nickel sample and skimmer cones (Spectron) were used. Rhodium was added to each sample as an internal standard for calibrating sensitivity shift of the instrument. Method accuracy and precision were assessed relative to Certified Reference Material CASS5 (Supplemental Table 1). All samples, including operational blanks, were corrected for recovery yield. Average values from the operational blanks were then subtracted from each sample for each time point such that the reported metal concentrations represent only aerosol-derived material.

Measurement of Co in natural seawater samples requires ultraviolet irradiation due to biogenic Co ligands (Saito et al., 2005; Milne et al., 2010; Shelley et al., 2010). Irradiation was not done in this study because the filtered seawater contained no organisms, and the dissolution from dust particles most likely does not create Co ligands, which are biological in origin. Moreover, we have not observed an excess of Co ligands in our speciation studies, and find them to be kinetically inert (non-exchangeable) in surface waters (Saito et al., 2005; Saito and Schneider, 2006) implying that Co-ligand complexes are likely formed intra-cellularly through enzymatic pathways such as the B12 biosynthetic pathway. As a result, the dissolution of Co from dust in this experiment would most likely remain labile and not exchange with the natural cobalt ligand pools.

\section{STATISTICAL APPROACHES}

Two types of statistical tests were included in the analysis of trace metal dissolution behavior for the data shown in Figure 3. First, to determine whether dissolution of individual metals were statistically different from each other, an ANOVA was conducted, followed by $t$-tests using the Bonferroni correction to account for multiple comparisons. Second, we calculated 95\% confidence intervals for the percent change in dissolved metal content for each metal over time. The 95\% confidence interval describes the range of values in which the mean is expected to fall $95 \%$ of the time. We used the confidence intervals to comment on the probable dissolution behavior of each metal. For example, confidence intervals that crossed the " $0 \%$ change" axis indicate that the metal has a high probability of showing instantaneous dissolution behavior. In contrast, confidence intervals falling entirely above the axis are more likely ( $95 \%$ of the time) to show gradual dissolution over time. Importantly, this approach allows metals that are 
not statistically different in pair wise analysis (such as Co and $\mathrm{Zn}$ ) to still be classified into separate groups based on their likelihood to dissolve slowly or rapidly.

\section{RESULTS AND DISCUSSION}

The dissolution experiment was conducted in aged seawater that was $0.2 \mu \mathrm{m}$ filtered prior to the experiment. Background metal concentration in the water are given in Table $\mathbf{1}$ and are compared to published concentrations for surface water in the Atlantic Ocean. $\mathrm{Al}, \mathrm{Cu}, \mathrm{Mn}$, and $\mathrm{Ni}$ were all within the expected range (Sohrin and Bruland, 2011), whereas the particle reactive metals $\mathrm{Fe}$ and $\mathrm{Pb}$ were lower than typical surface concentrations, likely due to sorption onto the walls of the carboy during storage. While close to the expected range, Co levels may be underestimated due to biogenic ligands in the seawater, as the samples were not UV irradiated prior to analysis, as discussed above (Saito et al., 2005; Saito and Schneider, 2006; Milne et al., 2010; Shelley et al., 2010). The metals Cd and Zn were slightly higher than typical surface water concentrations, likely due to low level contamination during the collection process.

\section{A CONTINUUM OF AEROSOL METAL DISSOLUTION}

The amount of each metal to dissolve from the aerosol samples was measured over time, and Figure 2 shows the dissolution time course with the concentration of each dissolved metal normalized to the mass of aerosol. Metal dissolution behavior occurred along a continuum, where some metals were more strongly influenced by particle reactivity, some dissolved rapidly, and others dissolved gradually over time (Figure 3, Table 3). Pair wise statistical analysis (Figure 3) demonstrates that rather than representing three discrete modes of dissolution, there is overlap between the groups due to variability that likely stems from the chemical and physical characteristics of each aerosol sample.

To determine which mode of dissolution metals in our samples resembled most closely, we calculated $95 \%$ confidence intervals, which show the range of values that the mean has a high $(95 \%)$ probability falling within (Figure 3). We designated metals with confidence intervals crossing the axis (which indicates no gain or loss in soluble metal content over time) as falling within the "instantaneous dissolution" region of the continuum. These included $\mathrm{Cd}$ and $\mathrm{Co}$ in our samples, which dissolved rapidly upon seawater exposure. For these metals up to 7 days of extended soaking yielded only small changes in dissolved metal concentration compared to samples measured immediately following seawater exposure (Figure 2).

Metals with confidence intervals falling completely above the axis ( $\mathrm{Zn}, \mathrm{Mn}, \mathrm{Cu}$, and $\mathrm{Al}$ in our samples) or completely below the axis (Fe and $\mathrm{Pb}$ in our samples) fell closer to the "gradual dissolution" and "particle reactive" ends of the continuum, respectively. While on average the largest percent increase in dissolution after 7 days of soaking was observed for $\mathrm{Al}$ (mean $=628 \%$; median $=$ $433 \% ;$ range $=71-1913 \%)$ and $\mathrm{Ni}($ mean $=559 \% ;$ median $=$
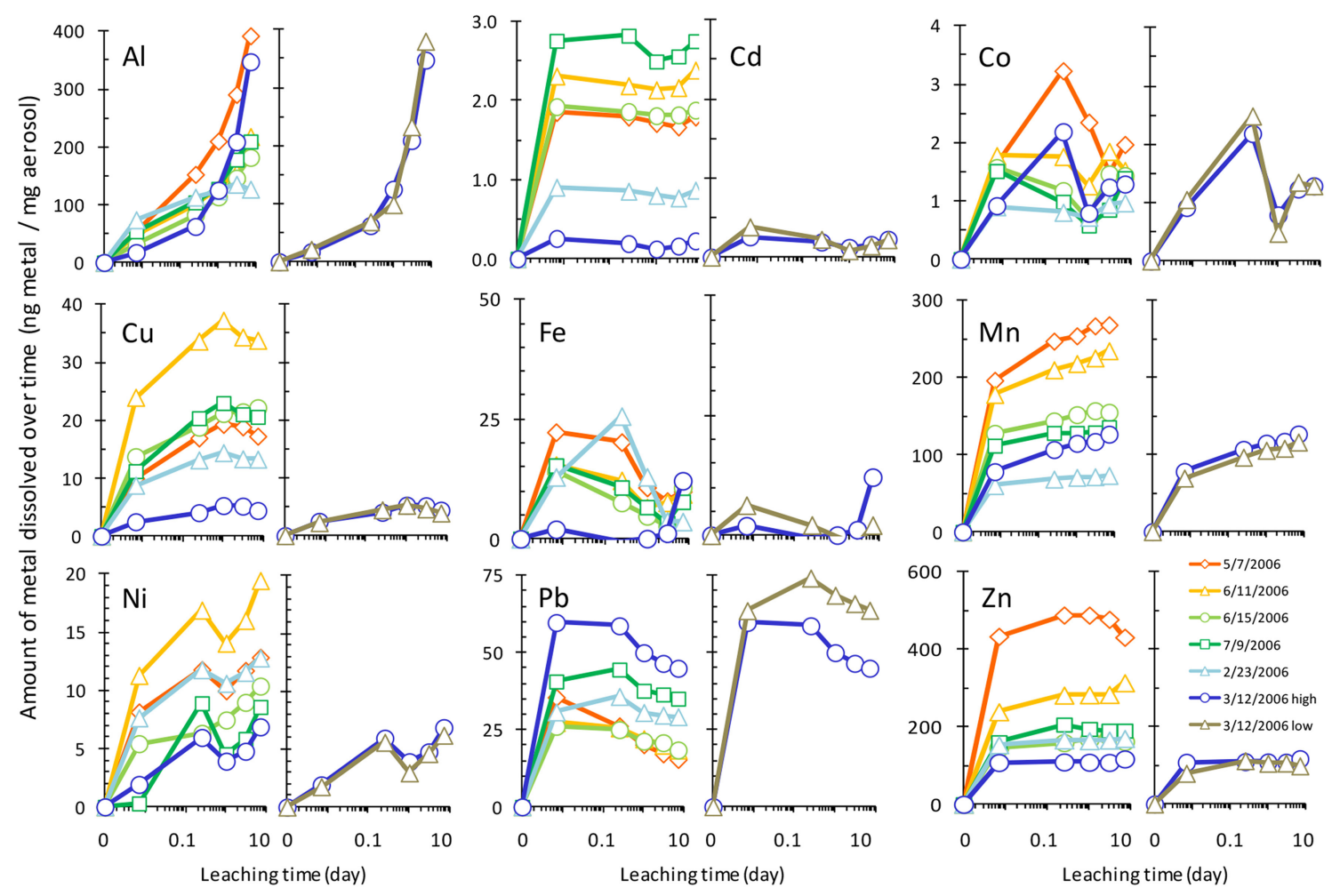

FIGURE 2 | Time series of aerosol metal dissolution after $10 \mathrm{~min}, \mathbf{6} \mathrm{h}, 1$ day, $\mathbf{3}$ days, and $\mathbf{7}$ days exposure to seawater. Leaching of the sample from $3 / 12 / 2006$ at two particle to solvent ratios is also shown for each metal (rightmost panels of each pair, denoted by "high" and "low" in legend). Raw data are provided in Supplemental Table 2. Legend in the " $\mathrm{Zn}$ " panel shows aerosol collection date. 


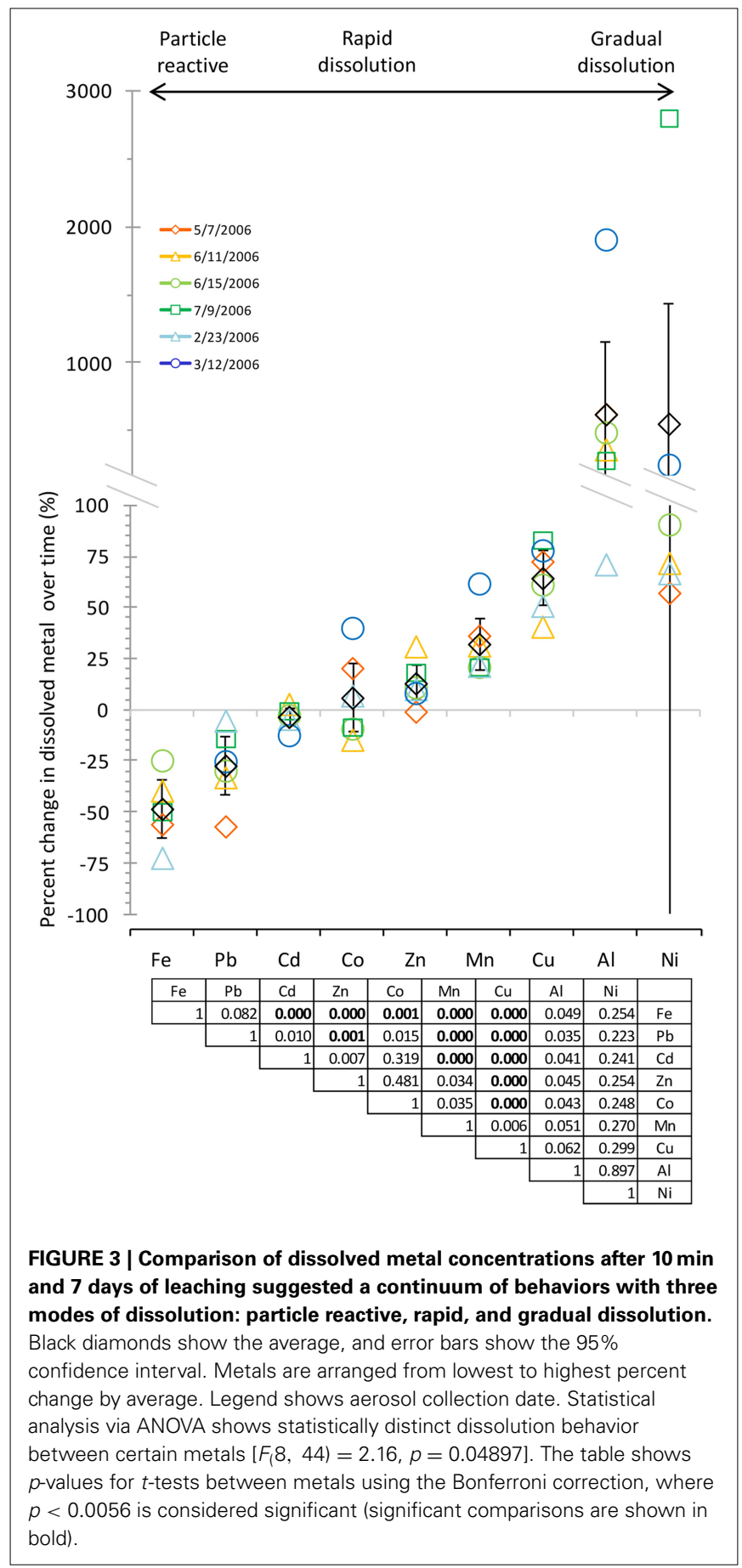

$82 \%$; range $=58-2806)$, enhanced dissolution over time was also observed for $\mathrm{Cu}($ mean $=65 \%$; median $=67 \%$; range $=41-83 \%)$ and $\mathrm{Mn}$ ( mean $=33 \%$; median $=27 \%$; range $=21-62 \%)$. In several samples but not all, Co also suggested a tendency to dissolve gradually over time (Figure 3 ).

The other end of the continuum includes particle reactive metals for which the dissolved concentrations decreased upon extended soaking in seawater. In our samples these included Fe $[$ mean $=-48 \% ;$ median $=-49 \%$; range $=-24-(-72 \%)]$ and
Table 3 | Percent solubility of aerosol trace metals in seawater after $10 \mathrm{~min}$ and 7 days of leaching.

\begin{tabular}{lccc}
\hline Metal & $\begin{array}{c}\text { Total mass of } \\
\text { metal per mass } \\
\text { of aerosol } \\
\text { (mean } \pm \text { SD) }\end{array}$ & $\begin{array}{c}\text { Percent } \\
\text { dissolved } \\
\text { after } \\
\mathbf{1 0} \text { min (\%) }\end{array}$ & $\begin{array}{c}\text { Percent } \\
\text { dissolved } \\
\text { after } \mathbf{7} \\
\text { days (\%) }\end{array}$ \\
\hline $\mathrm{Al}$ & $11.5 \pm 6.1 \mathrm{mg} / \mathrm{g}$ & $0.45 \pm 0.22$ & $2.5 \pm 1.0$ \\
$\mathrm{Cd}$ & $2.12 \pm 0.79 \mu \mathrm{g} / \mathrm{g}$ & $76 \pm 31$ & $74 \pm 33$ \\
$\mathrm{Co}$ & $9.88 \pm 4.33 \mu \mathrm{g} / \mathrm{g}$ & $17 \pm 10$ & $17 \pm 7$ \\
$\mathrm{Cu}$ & $84.7 \pm 37.4 \mu \mathrm{g} / \mathrm{g}$ & $14 \pm 5$ & $22 \pm 8$ \\
$\mathrm{Fe}$ & $24.5 \pm 10.3 \mathrm{mg} / \mathrm{g}$ & $0.066 \pm 0.039$ & $0.044 \pm 0.022$ \\
$\mathrm{Mn}$ & $461 \pm 121 \mu \mathrm{g} / \mathrm{g}$ & $28 \pm 12$ & $38 \pm 15$ \\
$\mathrm{Ni}$ & $53.7 \pm 28.0 \mu \mathrm{g} / \mathrm{g}$ & $12 \pm 10$ & $25 \pm 13$ \\
$\mathrm{~Pb}$ & $90.7 \pm 47.6 \mu \mathrm{g} / \mathrm{g}$ & $46 \pm 15$ & $32 \pm 10$ \\
$\mathrm{Zn}$ & $429 \pm 287 \mu \mathrm{g} / \mathrm{g}$ & $57 \pm 24$ & $65 \pm 30$ \\
\hline
\end{tabular}

$\mathrm{Pb}[$ mean $=-27 \%$; median $=-27 \%$; range $=-5-(-57 \%)]$. We did not observe net wall loss for $\mathrm{Zn}$; however, $\mathrm{Zn}$ is generally considered a particle reactive metal. The lack of wall loss in our experiment probably occurred due to the background concentrations of $\mathrm{Zn}$ in the seawater (Table 1), which may have saturated binding sites on the bottle walls and slowed the sorption of aerosol $\mathrm{Zn}$ to these surfaces. $\mathrm{Zn}$ may therefore display stronger or weaker particle reactive characteristics depending on the background levels of $\mathrm{Zn}$ in the leaching solvent.

We note that the dissolution behavior of many of the metals shows large degree of variability. For example, the confidence interval for $\mathrm{Ni}$, while crossing the axis, also extends far above and below the axis (the confidence interval range for $\mathrm{Ni}$ was -324 to $1442 \%)$. While all of the actual data points fell above the axis, the large variability in dissolution behavior is skewed by one very high data point, making the confidence interval very large. Other metals had smaller confidence intervals but still had inconsistent dissolution behavior between samples. For example, Co dissolution ranged from samples that were more particle reactive $(-14 \%$ for the $6 / 11 / 2006$ sample) to samples that dissolved gradually ( $40 \%$ for the $3 / 12 / 2006$ sample). Therefore, while on average the dissolution behavior of Co for the samples we tested here tends to be closest to the "instantaneous dissolution" region of the continuum, it is clear that different individual samples may behave differently. The variability would likely be expanded if samples with greater chemical heterogeneity were considered.

The percent of each metal dissolved relative to the total particulate metal concentrations (e.g., \% solubility) is reported for $10 \mathrm{~min}$ and 7 day time frames in Table 3. These data fall within the range of seawater solubility previously reported for aerosol samples from this region (Chen et al., 2006). The elemental molar ratio of metals in the bulk aerosols (e.g., the ratio based on total metal content in the aerosol) was 23,189Fe: 22,651Al: 445Mn: 348Zn: 71Cu: 48Ni: 23Pb: 9Co: 1Cd (Figure 4), whereas the ratio of seawater soluble metals after $10 \mathrm{~min}$ of leaching was 16Fe: 115Al: 154Mn: 213Zn: 12Cu: 7Ni: 12Pb: 2Co: $1 \mathrm{Cd}$ and after 7 days of leaching was 11Fe: 620Al: 205Mn: 240Zn: 20Cu: 14Ni: 9Pb: 2Co: $1 \mathrm{Cd}$. The seawater soluble ratios were calculated based on the relative soluble amount of each metal released into 


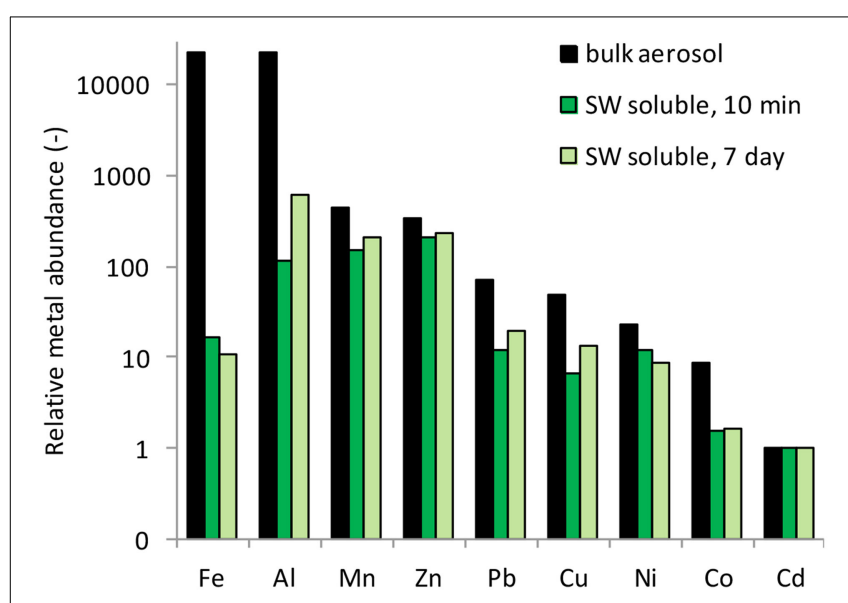

FIGURE 4 | Elemental molar ratios of metals in the bulk aerosol material, and in the seawater soluble fractions after $\mathbf{1 0}$ min and $\mathbf{7}$ days of leaching. Metals are arranged from most to least abundant based on the abundance in the bulk aerosol (black bars).

the filtrate, and show that amount of each metal in the soluble fraction differs considerably from that of the total metal content. Because of the large discrepancy between metal ratios in the bulk aerosol compared to the seawater soluble fraction, seawater soluble metal ratios should be reported wherever possible. This will allow models to incorporate aerosol measurements directly, rather than using bulk aerosol metal ratios and assuming percent solubilities, which are sensitive to leaching technique and can vary orders of magnitude depending on the metal in question.

\section{IMPLICATIONS FOR LEACHING PROTOCOLS AND MODELING}

Many studies have called for a unification of aerosol extraction protocols that would enable data to be compared between different research groups and geographical locations without methodological artifacts (Boyd et al., 2010; Measures et al., 2010; Buck and Paytan, 2012). Solvent, filter type, and duration have all been put forth as variables that should be standardized. Additionally, the relatively high particle to solvent ratio used in this and other aerosol extraction studies differs from conditions in the surface ocean, but is in some cases necessary to bring metal concentrations above detection limit. Boyd et al. (2010) suggest that longer term dissolution could be mimicked by using mineral acid leaching approaches or continuous flow methods to assess maximum Fe dissolution rates such as that described by Simonella et al. (2014). Alternative approaches have also been used to mimic the long term dissolution of Fe from volcanic ash in seawater (Duggen et al., 2007; Olgun et al., 2011) using an electrochemical method to prevent adsorption of the released Fe (Croot and Johansson, 2000).

Performing seawater leaching has the advantage of more closely mimicking the natural environment, but introduces other considerations. The chemical characteristics of seawater vary depending on source, making it difficult to standardize between laboratories. Wu et al. (2007) presented a semi-continuous flow through method for aerosol extraction, and suggest using seawater from the region of interest. This approach mimics characteristics the surface ocean closely, and is especially useful for characterizing metal dissolution over time. However, certain limitations remain; the effects of biological ligand production with time and photochemical redox transformations on aerosol metal solubility that occur in the surface ocean are not captured under laboratory conditions with filtered seawater. Additionally, obtaining sufficient volumes of seawater from regions of interest may not be feasible if the locations are remote, and variability could still be introduced due to seasonal variations in water chemistry. Nevertheless, this study supports using either semi-continuous flow through systems, longer leaching times or stronger solvents for metals such as $\mathrm{Al}, \mathrm{Cu}, \mathrm{Mn}$, and $\mathrm{Ni}$.

Another factor that can influence aerosol solubility is the particle to solute ratio. For sample 3/12/2006, we repeated the dissolution experiment using two different masses of aerosol added to the same volume of seawater to determine if the particle to solvent ratio influences the extent of dissolution. Dissolution was not strongly affected by the TSP to seawater ratio for most metals considered here; however, a particle concentration effect was observed for $\mathrm{Pb}$ (and possibly $\mathrm{Fe}$ ). For these particle reactive metals, dissolution was higher for smaller doses of aerosol with lower particle to solvent ratios. Approximately 15-20\% more $\mathrm{Pb}$ dissolved from the sample with lower particle mass (Figure 2). The effect was more difficult to quantify for Fe, where sorption of $\mathrm{Fe}$ onto the bottle wall and particles led to very low dissolved Fe concentrations, some of which were below detection limit.

Solubility of metals closer to the particle reactive end of the continuum ( $\mathrm{Fe}$ and $\mathrm{Pb}$ in our samples) would be underestimated using extended leaching procedures in pure water or seawater, but less so for extractions in acidic solution or semi-continuous flow approaches. Wall loss, precipitation, and (re)adsorption of metals like $\mathrm{Fe}$ and $\mathrm{Pb}$ onto particles, bottle walls, and filters exerts more control over soluble metal content in laboratory leaching experiments than in the surface ocean where the aerosol particle to solvent ratio is lower. Under natural conditions, these metals may show rapid or gradual dissolution patterns that are more similar to the other metals considered here, although the extent of dissolution would be more tightly liked to biota (e.g., ligand production in the case of $\mathrm{Fe}$ ) and particulate load (sorption onto lithogenic and biological particles in the case of $\mathrm{Pb}$ ). For these metals, instantaneous leaching methods or semi-continuous flow approaches such as those often used for Fe (Duggen et al., 2007; Olgun et al., 2011) would yield more accurate results than methods with longer leaching times.

Dissolved Al levels in seawater have been used to estimate atmospheric deposition to the ocean on a global scale. Dissolved $\mathrm{Al}$ is a robust proxy for atmospheric deposition in most locations, but the model tends to underestimate the amount of deposition in regions with high deposition rates (Measures and Vink, 2000). Factors like mixed layer depth, particle advection and $\mathrm{Al}$ solubility all contribute uncertainty to the model, and suggest that less cloud processing of dust in coastal, high-deposition regions could lead to lower solubility of Al (Measures and Vink, 2000) and other metals (Desboeufs et al., 2001, 2003). This study shows that $\mathrm{Al}$ dissolution continues up to 7 days after contacting seawater, and supports the idea that dissolution processes in seawater 
play an important role in determining the total solubility of $\mathrm{Al}$, in addition to clouds. As a result, the residence time of particulate $\mathrm{Al}$ in these coastal waters could strongly influence soluble $\mathrm{Al}$ levels by affecting time available for dissolution, sinking rate and acidic processing of particles through zooplankton digestion and excretion (Maring and Duce, 1987). Future studies to understand the effects of these processes on Al solubility are timely and could reduce uncertainty in atmospheric deposition models in regions with high deposition.

\section{ECOLOGICAL IMPLICATIONS}

Aerosols can at times provide "complete nutrition" for phytoplankton because they tend to supply macronutrients $(\mathrm{N}, \mathrm{P})$ together with metal micronutrients that can co-limit growth. Aerosol $\mathrm{N}$ is delivered as nitrate and ammonia, which are immediately soluble, and organic N, of which up to $30 \%$ is bioavailable (Peierls and Paerl, 1997). Aerosol P is delivered as phosphate and organic $\mathrm{P}$, and solubility is strongly related to particle origin (anthropogenic vs. crustal sources) (Mahowald et al., 2008; Anderson et al., 2010). Phytoplankton have evolved to take up $\mathrm{N}$ and $\mathrm{P}$ rapidly when these becomes available, and may perform luxury uptake to fuel growth once the community has depleted the ambient supply (Thingstad et al., 2005; Mackey et al., 2012b). Similar behavior is observed for metals like Fe, which can be stored in ferritin molecules within the cell (Marchetti et al., 2008). However, for other metal micronutrients this approach may not be used, owing to relatively lower biological demand and because metals can be toxic at high doses.

The effect of aerosol metals on phytoplankton growth will depend on the acclimation response time and uptake rate relative to the rate of dissolution. Following a large deposition event, biologically important metals that are rapidly soluble in seawater will be released in a large pulse, favoring species that have high metal demands and intracellular metal storage capacity (e.g., ferritin and similar storage strategies). In the case of Fe which is particle reactive over similar time scales relative to cell growth (Figure 2) and can rapidly precipitate from seawater if ligand levels are low, storage of $\mathrm{Fe}$ in ferritin molecules would provide a clear advantage because cells could claim bioavailable Fe before it is lost from the water. In contrast, gradually dissolving metals would be released more slowly over time, favoring sustained growth of species that are more competitive at lower metal concentrations.

Cellular acclimation to increased metal levels may also include the rapid biological production of ligands, which directly influence metal solubility. For example, Fe binding ligand concentrations increased $400 \%$ in 1-2 days following moderate Fe enrichment during the IronEx II study (Rue and Bruland, 1997), and $\mathrm{Cu}$ binding ligands doubled in response to dust additions in bottle experiments in the Sargasso Sea (Mackey et al., 2012a). In this study the concentrations of gradually dissolving metals increased an additional 33 to over $600 \%$ over a seven day period compared to initial amounts. In the open ocean phytoplankton typically double over 1-2 days, suggesting that ligand production rates could rapidly respond to changes in these metal concentrations within sufficient time to alter their solubility. Increased ligand production following atmospheric deposition events could serve to increase the solubility of certain metals and temper the biological responses of organisms by controlling the amount of free metal ions in the water.

The rate of dissolution will also affect toxicity, especially for metals like $\mathrm{Cd}, \mathrm{Cu}$, and $\mathrm{Ni}$. Ligand production may limit the toxicity of these elements by regulating the amount of free metal ions in solution. If organisms acclimate rapidly relative to the metal dissolution rate, toxicity may be avoided; this would be more likely for gradually dissolving metals but less likely for rapidly dissolving metals. The solubility of $\mathrm{Cu}$ is known to vary considerably between anthropogenic and crustal sources adding another layer of complexity; metals in anthropogenic aerosols have the potential to cause greater toxicity due to their more rapid dissolution and relatively higher total metal content compared to crustal source material (Sholkovitz et al., 2010). Whether aerosol metals cause toxicity will depend on how fast the community can acclimate by producing ligands, the overall uptake rate, the magnitude of the deposition event, the rate of metal dissolution, and the toxicity threshold of the population. Accumulation of metals like $\mathrm{Cu}$ and $\mathrm{Ni}$ has been observed in aerosol incubation studies following several days of exposure (Mackey et al., 2012a), and likely reflects the combination of low biological demand for and gradual dissolution of these metals over time.

\section{CONCLUSION}

In this study we investigated the role of extraction time on aerosol trace metal leaching behavior. Dissolution behaviors occurred along a continuum and considerable variability in dissolution exists between samples with different physical and chemical characteristics. Based on the confidence intervals of the dissolution patterns we measured in samples in this study, we identified that metals fell along different regions of the continuum, including rapid dissolution ( $\mathrm{Cd}$ and $\mathrm{Co}$ ), gradual dissolution $(\mathrm{Zn}, \mathrm{Mn}, \mathrm{Cu}$, and $\mathrm{Al}$ ), and dissolution that is affected by interactions with particles $(\mathrm{Fe}$ and $\mathrm{Pb}$ ). The dissolution kinetics of aerosol metals can influence bioavailable metal micronutrient inventories, and hence phytoplankton growth characteristics, in the surface ocean where particles may remain suspended and leach over a period of days. The different modes of dissolution behavior observed here suggest that to accurately understand and model the effect of atmospheric deposition on phytoplankton communities, the effects of extended leaching on different metals should be taken into consideration.

\section{ACKNOWLEDGMENTS}

We thank D. Golan at the Inter-University Institute for Marine Science in Eilat, Israel for collecting the aerosol samples, and R. Franks and K. Bruland for advice and assistance analyzing the aerosol extracts. All raw data and calibration information is provided in the Supplemental Information section. We also thank the three reviewers for their insightful comments to help improve the manuscript. This work was supported by NSF-OCE grant 0850467 to Adina Paytan, NSF-OCE grant 1233261 to Mak A. Saito, and NATO Science for Peace Grant to Adina Paytan and Anton F. Post (SfP 982161). Katherine R. M. Mackey was supported by a National Science Foundation Postdoctoral Research Fellowship in Biology (Grant No. NSF 1103575) and Chia-Te 
Chien by an international graduate student fellowship from the ministry of education, Taiwan.

\section{SUPPLEMENTARY MATERIAL}

The Supplementary Material for this article can be found online at: http://www.frontiersin.org/journal/10.3389/fmicb.2014. 00794/abstract

\section{REFERENCES}

Aguilar-Islas, A. M., Wu, J., Rember, R., Johansen, A. M., and Shank, L. M. (2010). Dissolution of aerosol-derived iron in seawater: leach solution chemistry, aerosol type, and colloidal iron fraction. Mar. Chem. 120, 25-33. doi: 10.1016/j.marchem.2009.01.011

Anderson, L. D., Faul, K. L., and Paytan, A. (2010). Phosphorus associations in aerosols: what can they tell us about P bioavailability? Mar. Chem. 120, 44-56. doi: 10.1016/j.marchem.2009.04.008

Baker, A. R., and Croot, P. L. (2010). Atmospheric and marine controls on aerosol iron solubility in seawater. Mar. Chem. 120, 4-13 doi: 10.1016/j.marchem.2008.09.003

Baker, A. R., Jickells, T. D., Witt, M., and Linge, K. L. (2006). Trends in the solubility of iron, aluminium, manganese and phosphorus in aerosol collected over the Atlantic Ocean. Mar. Chem. 98, 43-58. doi: 10.1016/j.marchem.2005.06.004

Barbeau, K., Rue, E. L., Bruland, K. W., and Butler, A. (2001). Photochemical cycling of iron in the surface ocean mediated by microbial iron(III)-binding ligands. Nature 413, 409-413 doi: 10.1038/35096545

Biller, D. V., and Bruland, K. W. (2012). Analysis of Mn, Fe, Co, Ni, Cu, Zn, Cd, and $\mathrm{Pb}$ in seawater using the Nobias-chelate PAl resin and magnetic sector inductively coupled plasma mass spectrometry (ICP-MS). Mar. Chem. 120, 12-20 doi: 10.1016/j.marchem.2011.12.001

Bonnet, S., and Guieu, C. (2004). Dissolution of atmospheric iron in seawater. Geophys. Res. Lett. 31:L03303. doi: 10.1029/2003GL018423

Boyd, P. W., Mackie, D. S., and Hunter, K. A. (2010). Aerosol iron deposition to the surface ocean-Modes of iron supply and biological responses. Mar. Chem. 120, 128-143 doi: 10.1016/j.marchem.2009.01.008

Boyle, E. A., Lee, J.-M., Echegoyen, Y., Noble, A., Moos, S., Carrasco, G., et al. (2014). Anthropogenic lead emissions in the ocean: the evolving global experiment. Oceanography 27, 69-75. doi: 10.5670/oceanog.2014.10

Bruland, K. W., and Franks, R. P. (1983). "Mn, Ni, Cu, Zn and Cd in the western North Atlantic," in Trace Metals in Seawater, NATO Conference Series IV; Marine Sciences, eds C. S. Wong, E. Boyle, K. W. Bruland, J. D. Burton, and E. D. Goldberg (New York, NY: Plenum Press), 395-414.

Buck, C. S., Landing, W. M., and Resing, J. (2013). Pacific ocean aerosols: deposition and solubility of iron, aluminum, and other trace elements. Mar. Chem. 157, 117-130 doi: 10.1016/j.marchem.2013.09.005

Buck, C. S., Landing, W. M., Resing, J. A., and Lebon, G. T. (2006). Aerosol iron and aluminum solubility in the northwest Pacific Ocean: results from the 2002 IOC cruise. Geochem. Geophys. Geosyst. 7, Q04M07. doi: 10.1029/2005GC000977

Buck, C. S., and Paytan, A. (2012). Evaluation of commonly used filter substrates for the measurement of aerosol trace element solubility. Limnol. Oceanogr. Methods 10, 790-806. doi: 10.4319/lom.2012.10.790

Chen, Y., Street, J., and Paytan, A. (2006). Comparison between pure-water- and seawater-soluble nutrient concentrations of aerosols from the Gulf of Aqaba. Mar. Chem. 101, 141-152 doi: 10.1016/j.marchem.2006.02.002

Croot, P. L., and Johansson, M. (2000). Determination of iron speciation by cathodic stripping voltammetry in seawater using the competing ligand 2-(2-Thiazolylazo)-p-cresol (TAC). Electroanalysis 12, 565-576. doi: 10.1002/(SICI)1521-4109(200005)12:8<565::AID-ELAN565>3.0.CO;2-L

Croot, P. L., Streu, P., and Baker, A. R. (2004). Short residence time for iron in surface seawater impacted by atmospheric dry deposition from Saharan dust events. Geophys. Res. Lett. 31, L23SL08. doi: 10.1029/2004GL020153

Dammshäuser, A., Wagener, T., Garbe-Schönberg, D., and Croot, P. (2013). Particulate and dissolved aluminum and titanium in the upper water column of the Atlantic Ocean. Deep Sea Res. Part I Oceanogr. Res. Pap. 73, 127-139. doi: 10.1016/j.dsr.2012.12.002

Davey, M., Tarran, G. A., Mills, M. M., Ridame, C., Geider, R. J., and LaRoche, J. (2008). Nutrient limitation of picophytoplankton photosynthesis and growth in the tropical North Atlantic. Limnol. Oceanogr. 53, 1722-1733. doi: $10.4319 /$ lo.2008.53.5.1722
Desboeufs, K. V., Losno, R., and Colin, J. L. (2001). Factors influencing aerosol solubility during cloud processes. Atmos. Environ. 35, 3529-3537. doi: 10.1016/S1352-2310(00)00472-6

Desboeufs, K. V., Losno, R., and Colin, J. L. (2003). Relationship between droplet $\mathrm{pH}$ and aerosol dissolution kinetics: effect of incorporated aerosol particles on droplet $\mathrm{pH}$ during cloud processing. J. Atmos. Chem. 46, 159-172. doi: 10.1023/A:1026011408748

Desboeufs, K. V., Losno, R., Vimeux, F., and Cholbi, S. (1999). The pH-dependent dissolution of wind-transported Saharan dust. J. Geophys. Res. Atmos. 104, 21287-21299. doi: 10.1029/1999JD900236

Desboeufs, K. V., Sofikitis, A., Losno, R., Colin, J. L., and Ausset, P. (2005). Dissolution and solubility of trace metals from natural and anthropogenic aerosol particulate matter. Chemosphere 58, 195-203. doi: 10.1016/j.chemosphere.2004.02.025

Duce, R. A., and Tindale, N. W. (1991). Atmospheric transport of iron and its deposition in the ocean. Limnol. Oceanogr. 36, 1715-1726 doi: 10.4319/lo.1991.36.8.1715

Duce, R. A., LaRoche, J., Altieri, K., Arrigo, K. R., Baker, A. R., Capone, D. G., et al. (2008). Impacts of atmospheric anthropogenic nitrogen on the open ocean. Science 320, 893-897. doi: 10.1126/science.1150369

Duggen, S., Croot, P., Schacht, U., and Hoffmann, L. (2007). Subduction zone volcanic ash can fertilize the surface ocean and stimulate phytoplankton growth: evidence from biogeochemical experiments and satellite data. Geophys. Res. Lett. 34, L01612. doi: 10.1029/2006GL027522

Giovagnetti, V., Brunet, C., Conversano, F., Tramontano, F., Obernosterer, I., Ridame, C., et al. (2013). Assessing the role of dust deposition on phytoplankton ecophysiology and succession in a low-nutrient low-chlorophyll ecosystem: a mesocosm experiment in the Mediterranean Sea. Biogeosciences 10, 2973-2991. doi: 10.5194/bg-10-2973-2013

Guieu, C., Dulac, F., Desboeufs, K., Wagener, T., Pulido-Villena, E., Grisoni, J.M., et al. (2010). Large clean mesocosms and simulated dust deposition: a new methodology to investigate responses of marine oligotrophic ecosystems to atmospheric inputs. Biogeosciences 7, 2765-2784. doi: 10.5194/bg-7-2765-2010

Guieu, C., Dulac, F., Ridame, C., and Pondaven, P. (2014). Introduction to project DUNE, a DUst experiment in a low Nutrient, low chlorophyll Ecosystem. Biogeosciences 11, 425-442. doi: 10.5194/bg-11-425-2014

Heller, M. I., and Croot, P. L. (2011). Superoxide decay as a probe for speciation changes during dust dissolution in Tropical Atlantic surface waters near Cape Verde. Mar. Chem. 126, 37-55. doi: 10.1016/j.marchem.2011.03.006

Herut, B., Krom, M. D., Pan, G., and Mortimer, R. (1999). Atmospheric input of nitrogen and phosphorus to the southeast Mediterranean: sources, fluxes, and possible impact. Limnol. Oceanogr. 44, 1683-1692 doi: 10.4319/lo.1999.44.7.1683

Hydes, D. J. (1983). Distribution of aluminium in waters of the north east Atlantic $25^{\circ} \mathrm{N}$ to $35^{\circ} \mathrm{N}$. Geochim. Cosmochim. Acta 47, 967-973. doi: 10.1016/00167037(83)90164-3

Jones, M. T., and Gislason, S. R. (2008). Rapid releases of metal salts and nutrients following the deposition of volcanic ash into aqueous environments. Geochim. Cosmochim. Acta, 72, 3661-3680. doi: 10.1016/j.gca.2008.05.030

Jordi, A., Basterretxea, G., Tovar-Sánchez, A., Alastuey, A., and Querol, X. (2012). Copper aerosols inhibit phytoplankton growth in the Mediterranean Sea. Proc. Natl. Acad. Sci. U.S.A. 109, 21246-21249 doi: 10.1073/pnas.1207567110

Journet, E., Desboeufs, K. V., Caquineau, S., and Colin, J.-L. (2008). Mineralogy as a critical factor of dust iron solubility. Geophys. Res. Lett. 35:L07805. doi: 10.1029/2007GL031589

Laghdass, M., Blain, S., Besseling, M., Catala, P., Guieu, C., and Obernosterer, I. (2011). Effects of Saharan dust on the microbial community during a large in situ mesocosm experiment in the NW Mediterranean Sea. Aquat. Microb. Ecol. 62, 201-213. doi: 10.3354/ame01466

Langlois, R. J., Mills, M. M., Ridame, C., Croot, P., and LaRoche, J. (2012). Diazotrophic bacteria respond to Saharan dust additions. Mar. Ecol. Prog. Ser. 470, 1-14. doi: 10.3354/meps10109

Mackey, K. R. M., Buck, K. N., Casey, J. R., Cid, A., Lomas, M. W., Sohrin, Y., et al. (2012a). Phytoplankton responses to atmospheric metal deposition in the coastal and open-ocean Sargasso Sea. Front. Microbiol. 3:359. doi: 10.3389/fmicb.2012.00359

Mackey, K. R. M., Mioni, C. E., Ryan, J. P., and Paytan, A. (2012b). Phosphorus cycling in the red tide incubator region of Monterey Bay in response to upwelling. Front. Microbiol. 3:33. doi: 10.3389/fmicb.2012.00033 
Mackey, K. R. M., Roberts, K., Lomas, M. W., Post, A. F., Saito, M., and Paytan, A. (2012c). Enhanced solubility and ecological impact of atmospheric phosphorus deposition upon extended seawater exposure. Environ. Sci. Technol. 46, 10438-10446. doi: 10.1021/es3007996

Mahowald, N., Jickells, T. D., Baker, A. R., Artaxo, P., Benitez-Nelson, C. R., Bergametti, G., et al. (2008). Global distribution of atmospheric phosphorus sources, concentrations and deposition rates, and anthropogenic impacts. Global Biogeochem. Cycles 22, GB4026. doi: 10.1029/2008GB003240

Mahowald, N. M., Baker, A. R., Bergametti, G., Brooks, N., Duce, R. A., Jickells, T. D., et al. (2005). The atmospheric global dust cycle and iron inputs to the ocean. Global Biogeochem. Cycles 19, GB4025. doi: 10.1029/2004GB 002402

Marchetti, A., Parker, M. S., Moccia, L. P., Lin, E. O., Arrieta, A. L., Ribalet, F., et al. (2008). Ferritin is used for iron storage in bloomforming marine pennate diatoms. Nature 457, 467-470 doi: 10.1038/nature 07539

Maring, H. B., and Duce, R. A. (1987). The impact of atmospheric aerosols on trace metal chemistry in open ocean surface seawater, 1. Aluminum. Earth Planet. Sci. Lett. 84, 381-392 doi: 10.1016/0012-821X(87)90003-3

Martin, J. H., Fitzwater, S. E., Gordon, R. M., Hunter, C. N. and Tanner, S. J. (1993). Iron, primary production, and carbon-nitrogen flux studies during the JGOFS North Atlantic bloom experiment. Deep Sea Res. 40, 115-134. doi: 10.1016/0967-0645(93)90009-C

Measures, C. A., Sato, T., Vink, S., Howell, S., and Li, Y. H. (2010). The fractional solubility of aluminium from mineral aerosols collected in Hawaii and implications for atmospheric deposition of biogeochemically important trace elements. Mar. Chem. 120, 144-153 doi: 10.1016/j.marchem.2009.01.014

Measures, C. A., and Vink, S. (2000). On the use of dissolved aluminum in surface waters to estimate dust deposition to the ocean. Global Biogeochem. Cycles 14, 317-327 doi: 10.1029/1999GB001188

Mendez, J., Guieu, C., and Adkins, J. (2010). Atmospheric input of manganese and iron to the ocean: seawater dissolution experiments with Saharan and North American dusts. Mar. Chem. 120, 34-43. doi: 10.1016/j.marchem.2008.08.006

Mills, M. M., Ridame, C., Davey, M., and La Roche, J. (2004). Iron and phosphorus co-limit nitrogen fixation in the eastern tropical North Atlantic. Nature 429, 292-294. doi: 10.1038/nature02550

Milne, A., Landing, W., Bizimis, M., and Morton, P. (2010). Determination of Mn, $\mathrm{Fe}, \mathrm{Co}, \mathrm{Ni}, \mathrm{Cu}, \mathrm{Zn}, \mathrm{Cd}$ and $\mathrm{Pb}$ in seawater using high resolution magnetic sector inductively coupled mass spectrometry (HR-ICP-MS). Anal. Chim. Acta 665, 200-207. doi: 10.1016/j.aca.2010.03.027

Moore, C. M., Mills, M. M., Milne, A., Langlois, R., Achterberg, E. P., Lochte, K., et al. (2006). Iron limits primary productivity during spring bloom development in the central North Atlantic. Glob. Change Biol. 12, 626-634. doi: 10.1111/j.1365-2486.2006.01122.x

Morel, F. M. M., and Price, N. M. (2003). The biogeochemical cycles of trace metals in the oceans. Science 300, 944-947. doi: 10.1126/science.1083545

Morel, F. M. M., Reinfelder, J. R., Roberts, S. B., Chamberlain, C. P., Lee, J. G., and Yee, D. (1994). Zinc and carbon co-limitation of marine phytoplankton. Nature 369, 740-742. doi: 10.1038/369740a0

Noble, A. E., Saito, M. A., Maiti, K., and Benitez-Nelson, C. R. (2008). Cobalt, manganese, and iron near the Hawaiian Islands: a potential concentrating mechanism for cobalt within a cyclonic eddy and implications for the hybrid-type trace metals. Deep Sea Res. II Top. Stud. Oceanogr. 55, 1473-1490. doi: 10.1016/j.dsr2.2008. 02.010

Olgun, N., Duggen, S., Croot, P. L., Delmelle, P., Dietze, H., Schacht, U., et al. (2011). Surface ocean iron fertilization: the role of airborne volcanic ash from subduction zone and hot spot volcanoes and related iron fluxes into the Pacific Ocean. Global Biogeochem. Cycles 25, GB4001. doi: 10.1029/2009GB003761

Paerl, H. W. (1997). Coastal eutrophication and harmful algal blooms: importance of atmospheric deposition and groundwater as "new" nitrogen and other nutrients. Limnol. Oceanogr. 42, 1154-1165. doi: 10.4319/lo.1997.42.5_part_2.1154

Paris, R., and Desboeufs, K. V. (2013). Effect of atmospheric organic complexation on iron-bearing dust solubility. Atmos. Chem. Phys. Discuss. 13, 3179-3202. doi: 10.5194/acpd-13-3179-2013

Paris, R., Desboeufs, K. V., Formenti, P., Nava, S., and Chou, C. (2010). Chemical characterisation of iron in dust and biomass burning aerosols during AMMA-SOP0/DABEX: implication for iron solubility. Atmos. Chem. Phys. 10, 4273-4282. doi: 10.5194/acp-10-4273-2010
Paris, R., Desboeufs, K. V., and Journet, E. (2011). Variability of dust iron solubility in atmospheric waters: investigation of the role of oxalate organic complexation. Atmos. Environ. 45, 6510-6517. doi: 10.1016/j.atmosenv.2011. 08.068

Paytan, A., Mackey, K. R. M., Chen, Y., Lima, I. D., Doney, S. C., Mahowald, N., et al. (2009). Toxicity of atmospheric aerosols on marine phytoplankton. Proc. Natl. Acad. Sci. U.S.A. 106, 4601-4605. doi: 10.1073/pnas.0811 486106

Peierls, B. L., and Paerl, H. W. (1997). The bioavailability of atmospheric organic nitrogen deposition to coastal phytoplankton. Limnol. Oceanogr. 42, 1819-1823. doi: 10.4319/lo.1997.42.8.1819

Prospero, J. M., and Savoie, D. L. (1989). Effect of continental sources on nitrate concentrations over the Pacific Ocean. Nature 339, 687-689. doi: $10.1038 / 339687 \mathrm{a} 0$

Ridame, C., and Guieu, C. (2002). Saharan input of phosphate to the oligotrophic water of the open western Mediterranean Sea. Limnol. Oceanogr. 47, 856-869. doi: 10.4319/lo.2002.47.3.0856

Ridame, C., Guieu, C., and L'Helguen, S. (2013). Strong stimulation of N2 fixation in oligotrophic Mediterranean Sea: results from dust addition in large in situ mesocosms. Biogeosciences 10, 7333-7346. doi: 10.5194/bg-10-73 33-2013

Rue, E. L., and Bruland, K. W. (1997). The role of organic complexation on ambient iron chemistry in the equatorial Pacific Ocean and the response of a mesoscale iron addition experiment. Limnol. Oceanogr. 42, 901-910 doi: 10.4319/lo.1997.42.5.0901

Saito, M. A., Bertrand, E. M., Dutkiewicz, S., Bulygin, V. V., Moran, D. M., Monteiro, F. M., et al. (2011). Iron conservation by reduction of metalloenzyme inventories in the marine diazotroph Crocosphaera watsonii. Proc. Natl. Acad. Sci. U.S.A. 108, 2184-2189. doi: 10.1073/pnas.1006943108

Saito, M. A., and Goepfert, T. J. (2008). Zinc-cobalt colimitation of Phaeocystis Antarctica. Limnol. Oceanogr. 53, 266-275. doi: 10.4319/lo.2008.53.1.0266

Saito, M. A., and Moffett, J. W. (2002). Temporal and spatial variability of cobalt in the Atlantic Ocean. Geochim. Cosmochim. Acta 66, 1943-1953 doi: 10.1016/S0016-7037(02)00829-3

Saito, M. A., Moffett, J. W., Chisholm, S. W., and Waterbury, J. B. (2002). Cobalt limitation and uptake in Prochlorococcus. Limnol. Oceanogr. 47, 1629-1636. doi: 10.4319/lo.2002.47.6.1629

Saito, M. A., Rocap, G., and Moffett, J. W. (2005). Production of cobalt binding ligands in a Synechococcus feature at the Costa Rica upwelling dome. Limnol. Oceanogr. 50, 279-290. doi: 10.4319/lo.2005.50.1.0279

Saito, M. A., and Schneider, D. L. (2006). Examination of precipitation chemistry and improvements in precision using the $\mathrm{Mg}(\mathrm{OH}) 2$ preconcentration inductively coupled plasma mass spectrometry (ICP-MS) method for highthroughput analysis of open-ocean Fe and $\mathrm{Mn}$ in seawater. Anal. Chim. Acta 565, 222-233. doi: 10.1016/j.aca.2006.02.028

Shelley, R. U., Zachhuber, B., Sedwick, P. N., Worsfold, P. J., and Lohan, M. C. (2010). Determination of total dissolved cobalt in UV-irradiated seawater using flow injection with chemiluminescence detection. Limnol. Oceanogr. Methods 8, 352-362. doi: 10.4319/lom.2010.8.352

Sholkovitz, E. R., Sedwick, P. N., and Church, T. M. (2010). On the fractional solubility of copper in marine aerosols: the toxicity of aeolian copper revisited. Geophys. Res. Lett. 37, L20601. doi: 10.1029/2010GL044817

Simonella, L. E., Gaiero, D. M., and Palomeque, M. E. (2014). Validation of a continuous flow method for the determination of soluble iron in atmospheric dust and volcanic ash. Talanta 128, 248-253. doi: 10.1016/j.talanta.2014. 04.076

Sohrin, Y., and Bruland, K. W. (2011). Global status of trace elements in the ocean. Trends Analyt. Chem. 30, 1291-1307. doi: 10.1016/j.trac.2011.03.006

Sohrin, Y. S., Urushihara, S., Nakatsuka, T., Kono, E., Higo, T., Minami, K., et al. (2008). Multi-elemental determination of GEOTRACES key trace metals in seawater by ICPMS after preconcentration using an ethylenediaminetriacetic acid chelating resin. Anal. Chem. 80, 6267-6273. doi: 10.1021/ ac800500f

Statham, P. J., Yeats, P. A., and Landing, W. M. (1998). Manganese in the eastern Atlantic Ocean: processes influencing deep and surface water distributions. Mar. Chem. 61, 55-68. doi: 10.1016/S0304-4203(98)00007-3

Thingstad, T. F., Krom, M. D., Mantoura, R. F. C., Flaten, G. A. F., Groom, S., Herut, B., et al. (2005). Nature of phosphorus limitation in the ultraoligotrophic Eastern Mediterranean. Science 309, 1068-1071. doi: 10.1126/science.1112632 
Thuroczy, C.-E., Boye, M., and Losno, R. (2010). Dissolution of cobalt and zinc from natural and anthropogenic dusts in seawater. Biogeosciences 7, 1927-1936 doi: 10.5194/bg-7-1927-2010

Wu, J., Rember, R., and Cahill, C. (2007). Dissolution of aerosol iron in the surface waters of the North Pacific and North Atlantic oceans as determined by a semicontinuous flow-through reactor method. Global Biogeochem. Cycles 21, GB4010. doi: 10.1029/2006GB002851

Wuttig, K., Heller, M. I., and Croot, P. L. (2013a). Pathways of superoxide (O2) decay in the Eastern Tropical North Atlantic. Environ. Sci. Technol. 47, 10249-10256. doi: 10.1021/es401658t

Wuttig, K., Heller, M. I., and Croot, P. L. (2013b). Reactivity of inorganic Mn and $\mathrm{Mn}$ desferrioxamine B with O2, O2-, and $\mathrm{H} 2 \mathrm{O} 2$ in Seawater. Environ. Sci. Technol. 47, 10257-10265. doi: 10.1021/es4016603

Wuttig, K., Wagener, T., Bressac, M., Dammshäuser, A., Streu, P., Guieu, C., et al. (2013c). Impacts of dust deposition on dissolved trace metal concentrations ( $\mathrm{Mn}, \mathrm{Al}$ and $\mathrm{Fe}$ ) during a mesocosm experiment. Biogeosciences 10, 2583-2600 doi: 10.5194/bg-10-2583-2013

Zhu, X. R., Prospero, J. M., and Millero, F. J. (1997). Diel variability of soluble $\mathrm{Fe}(\mathrm{II})$ and soluble total Fe in North African dust in the trade winds at Barbados. J. Geophys. Res. Atmos. 102, 21297-21305. doi: 10.1029/97 JD01313
Zhuang, G., Duce, R. A., and Kester, D. R. (1990). The dissolution of atmospheric iron in surface seawater of the open ocean. J. Geophys. Res. Oceans 95 , 16207-16216. doi: 10.1029/JC095iC09p16207

Conflict of Interest Statement: The authors declare that the research was conducted in the absence of any commercial or financial relationships that could be construed as a potential conflict of interest.

Received: 20 May 2014; accepted: 23 December 2014; published online: 21 January 2015.

Citation: Mackey KRM, Chien C-T, Post AF, Saito MA and Paytan A (2015) Rapid and gradual modes of aerosol trace metal dissolution in seawater. Front. Microbiol. 5:794. doi: 10.3389/fmicb.2014.00794

This article was submitted to Microbiological Chemistry and Geomicrobiology, a section of the journal Frontiers in Microbiology.

Copyright (c) 2015 Mackey, Chien, Post, Saito and Paytan. This is an open-access article distributed under the terms of the Creative Commons Attribution License (CC BY). The use, distribution or reproduction in other forums is permitted, provided the original author(s) or licensor are credited and that the original publication in this journal is cited, in accordance with accepted academic practice. No use, distribution or reproduction is permitted which does not comply with these terms. 